\title{
Using Micro-Level Data to Map State Failure: The Example of Somalia
}

\author{
ANNA MAEDL, ROOS HAER AND \\ MICHAEL ODENWALD
}

\begin{abstract}
In the study of state failure, scholars and practitioners have mostly focused on macro-level indicators to determine which state is failed and which is not. This focus overlooks crucial local and regional variation that has to be taken into account when designing interventions. In this article, we develop a new approach to examine state failure on this microlevel. Using a unique data-set on Somalia, we identify micro-level indicators for state failure. The analysis shows that micro-level data are crucial for detecting variation in state failure.
\end{abstract}

\section{INTRODUCTION}

Today, the international community is confronted with several so-called failed states, which show little prospect of recovery. These particular states are characterised by the absence of a central authority that can provide security for its citizens or deliver other essential public services. In addition, failed states are not able to support democratic elections or any other forms of collective decision making. In contrast, they often generate highly visible violations of human rights.' As a result, these states pose grave dangers to regional and international stability. State weakness negatively impacts neighbouring countries' economies and security and it can provide safe havens for terrorist organisations and centres of criminal activity. ${ }^{2}$ To put it differently, the longer a failed state persists, the greater the potential challenges to its own population, neighbouring states and international peace.

To counter this failure, many humanitarian assistance activities are not only designed to alleviate the immediate suffering of the civilian population, but also to contribute to an overall framework of statebuilding. ${ }^{3}$ However, most of these activities have shown little success in mitigating state failure. ${ }^{4}$ Heathershaw and Lambach offer two important explanations for this lack of success in current postconflict approaches. ${ }^{5}$ First, most humanitarian assistance activities are based on a macro-level vantage point, and thus designed from an 'outsider's perspective'. Second, most of these post-conflict interventions are rarely connected to the scholarly discourse on state failure and vice versa. ${ }^{6}$

In this article, we will contribute to bridging these two gaps by analysing Somalia as a failed state from a micro-level perspective rather than from an 
'outsider' macro-perspective. As such, we aim to bring the scholarly community closer to what practitioners are facing when working in the field in Somalia. This country is often regarded as the case of a totally failed state. Since 1991, it has had no functioning government, little security, endemic armed conflict, and high levels of unemployment and criminality.? However, a closer look at the country reveals an impressive but fragile level of local governance. ${ }^{8}$ Local communities are not passive in the face of state failure. Rather, they seek arrangements that help them to provide their population with core services that would have been otherwise provided by state authorities. In other words, local communities adapt in a variety of ways to minimise the risk and increase the predictability in their dangerous environments. ${ }^{9}$ The most visible manifestations of these functioning local communities are the formal selfdeclared administrations of Somaliland and Puntland. These two Northern regions have developed a central authority that provides their population with at least some public goods. ${ }^{10}$

Even though some studies have pointed towards these local differences within a failed state, the variation in the level of governance between regions has not yet been translated into the empirical state failure literature. " This is largely due to the lack of consistent and systematic data that identify certain state failure indicators on the local or even individual level. However, in this article, we present unique descriptive data from quantitative interviews with more than 8,000 Somali combatants. These interviews were held in 2003 and provide us with the opportunity to examine state failure variation in all its facets. This opens a new opportunity to identify indicators that reflect the dynamic concept of state failure, which can be used to design more effective interventions.

\section{STATE FAILURE}

With the disintegration of the Soviet Union at the end of the Cold War, the fragility not only of the international system, but also of states themselves, became evident. In many states and entire regions, conflict broke out, large-scale human rights violations became readily visible and economic security was nowhere to be found. This led to a massive and very diverse body of literature on the so-called state failure. However, why particular states failed and more importantly what constitutes this failure is a matter of debate.

A major strand of this debate surrounds the link between violent conflict and state failure. ${ }^{12}$ Some scholars employ proxies for the onset of civil war as indicators of state failure. ${ }^{13}$ In addition, some of the best-known state failure indices also focus on this linkage. ${ }^{14}$ This is for example, reflected by the name of the coding manual of The Fund for Peace's Failed States Index, which is called 'Conflict Assessment System Tool'. ${ }^{15}$ Also the Political Instability Task Force addresses this linkage in their first report in which they state that they were actually not exclusively examining failed states, because there were too few cases to use the chosen statistical methods. ${ }^{16}$

Another strand of criticisim is directed against the apparent ethnocentric elements in the concept of state failure. Some scholars argue that state failure takes 
the European Westphalia state as a model, which cannot necessarily be applied to all cultures and forms of organising human communities. ${ }^{17}$ Using the concept of state failure to force these communities into Westphalian states would in this reading be 'interventionist' and 'neocolonialistic'. ${ }^{18}$

At the same time, other scholars questionned the usefulness of the concept as its measurement remains unclear. In other words, they are more concerned about the empirical aspect rather than the political conceptual elements of state failure. ${ }^{19}$ For example, many empirical indicators of state failure are at the same time part of standard development indices. The most prominent examples are child mortality and gross domestic product (GDP). However, as Englehart states, those countries, which score worst on development indices, are not necessarily failed states and stark forms of underdevelopment cannot be equated with state failure..$^{20}$

Acknowledging this problem of causality, i.e. whether state failure causes underdevelopment or conflict or vice versa, we consider these discussions crucial to foster our understanding of this dynamic concept. ${ }^{21} \mathrm{We}$ do, therefore, not agree with some scholars to reject state failure as a concept since it is used in so many different ways that it can no longer be viewed as a useful entity of analysis. ${ }^{22}$ However, our understanding of state failure is more encompassing that just armed conflicts or underdevelopment. ${ }^{23}$

We consider state failure more in line with Bates et al., who essentially argue that it is the deterioration of the ability of the central authority to provide public goods for its citizens. ${ }^{24} \mathrm{~A}$ state constitutes an equilibrium situation, in which citizens grant the government the monopoly of violence in return for the protection of their wealth and the provision public services. ${ }^{25}$ However, when the state fails to deliver security to its population because it becomes increasingly authoritarian and predatory, citizens will withdraw their support and turn to violence to acquire the necessary goods from each other ${ }^{26}$ Several other scholars have also highlighted the role of authoritarian regimes and predatory elites in state failure. ${ }^{27}$

The above discussion illustrates that the concept of failed states is highly problematic. Some might even call it a hollow concept. However, not only in academics but also in the policy-making community, the concept of failed states is frequently used. Indeed, today the terms 'weak', 'fragile', 'failing', 'disintegrating', 'fragmented' and 'collapsing states', as well as 'quasi states', 'shadow states', 'phantom states', 'private states' and 'Low Income Countries Under Stress' are all employed to describe states that fail to serve its citizens.

However, if we define states as entities that are able to perform basic government functions such as providing public goods, they clearly vary in the range of activities they engage in as well as in their capability to implement their agendas. ${ }^{28}$ As a result, state failure has to be conceptualised as a continuum; a state is neither collapsed nor fully functioning. ${ }^{29}$ The level of failure varies not only between countries but also over time; states can slide back and forth on the continuum of state failure. The less able a state is to fulfil its role, the closer it is to state failure. ${ }^{30}$ Clapham has, therefore, described statehood as 'relative'. ${ }^{31}$ 
Acknowledging the variance of state failure over time and between countries is only one way to approach this relative concept. What is in general lacking in the current studies on state failure is the idea that this failure might also vary within a country at a given point in time. For example, state power might reach particular regions, while others are untouched. More importantly, alternative sources of authority might develop in those areas where the state is unable to perform its basic functions. The more these alternative authorities take over state functions, the less the repercussions of state failure will be felt within the region. These alternative authorities can consist of kinship networks as well as religious and other organisations, such as armed groups.

Although the existence of armed groups contributes to state failure, they sometimes behave like state authorities within the territories they hold. In some cases, they provide public goods and infrastructure, collect taxes and mediate conflicts. $^{32}$ They might even have international representation, be involved in extensive legal and illegal international trade networks and sponsor 'diplomatic' relationships with sovereign states and other movements. ${ }^{33}$ As such, they replace state authority by their own and have become an alternative source of authority which often enjoys a considerable amount of acceptance and legitimacy. ${ }^{34}$

The possibility of micro-level variation of state failure is in general overlooked by current research. This is due to the fact that most rankings and indices of state failure exclusively employ highly aggregated data like national economical or development measures such as the GDP, child mortality estimators or literacy rates. Rice and Patrick, for example, have produced their own index of state fragility using 11 different macro-level databases, ranging from the UNICEF's State of the World's Children data to the Political Instability Task Force's data. ${ }^{35}$ Also most other existing indices of state failure, like those described above, have mainly focused on macro-level indicators.

\section{SOMALIA: A FAILURE AMONG FAILED STATES?}

We use Somalia as a case study to emphasise the importance of using micro-level data to measure variation in state failure. In 2003, when our data were collected, Somalia was ranked as one of the four fully collapsed states by the Failed States Index. ${ }^{36}$ It has now held this status for almost two decades. Several attempts by the international community, including two United Nations peacekeeping missions, failed to substantially improve the situation and move Somali to the other side of the state failure continuum.

However, a window of opportunity to improve the Somali situation opened in 2002 by the initiation of the so-called Somali National Reconciliation Conference (Eldoret Conference). A ceasefire agreement was signed, but fighting between and within different militia factions persisted, bandits continued to plague the country and Somalia was allegedly harbouring international Islamic terrorist groups. ${ }^{37}$ In 2005, the World Bank estimated 70,000-80,000 active militia in Somalia. ${ }^{38}$ A number that is probably also correct for 2003. 
While armed violence remained widespread after the ceasefire, the nature of the confrontations changed in comparison to the early 1990s. The fighting during and after the fall of Siad Barre's regime was mainly between clans, which were seeking to establish control over what they perceived to be their respective territories. ${ }^{39}$ In contrast, armed conflict in 2003 was not as widespread. Rather, it was limited to specific localities, claiming fewer casualties and following vague political agendas. ${ }^{40}$ Somalia in 2003 clearly remained a fully collapsed state. However, some areas in the North enjoyed relative peace while others such as the Mogadishu region in the South witnessed major armed violence. ${ }^{41}$

Warlords throughout the country were able to collect taxes and tolls from the local population in the areas under control. However, most of them were not committed to providing any public goods and services in return. ${ }^{42}$ Only few local authorities were able to fulfil some 'state-like' functions such as upholding law and order and providing a minimum of public goods and services. Apart from these local authorities, the rather peaceful situation in the Northern part of Somalia led to the development of autonomous administrations in Somaliland and Puntland..$^{43}$

Although Somaliland still remains unrecognised by the international community, it had and continues to have a reasonable functioning government and bureaucracy which was to some degree able to collect taxes and provide social services with the help of civil and religious organisations. ${ }^{44}$ However, the government was struggling for their monopoly of power since peace was largely upheld by local politicians and elders. Moreover, the government was not always supported throughout Somaliland. Especially, the Eastern part of Somaliland showed resentment. As a result, although relatively peaceful in comparison to the rest of Somalia, violent conflict still occurred in Somaliland in 2003.

Similar to Somaliland, Puntland, another Northern region of Somalia, established its own government with some success. However, unlike Somaliland, Puntland has repeatedly stated its willingness to join Somalia once it would re-establish a functioning government. ${ }^{45}$ Puntland and Somaliland were involved in an ongoing border dispute in 2003 as both regions claimed the Sool and Sanaag territories. Towards the end of the year, this conflict resulted in armed clashes between the special forces of Puntland with the local militia. ${ }^{46}$ Moreover, Puntland is struggling with the continuation of illegal arms flowing into its region from Ethiopia. ${ }^{47}$ However, besides these problems, Puntland was relatively peaceful and functioning as an autonomous region throughout 2003 in comparison to the rest of Somalia.

The situation further South of Somalia looked different. In Kismayo, the Juba Valley Alliance militia provided some regional authority throughout 2003. They claimed to have set up a functioning local administration in which they allegedly had control over the police, court and prison services. ${ }^{48}$ However, many observers considered this militia an occupying force, whose main interest was to control the Kismayo port rather than to provide the population with a fully functioning administration that would provide public goods and services. ${ }^{49}$ Nevertheless, the Kismayo region was enjoying some peace because one rather than many militias 
dominated it. However, fighting periodically flared up and claimed many civilian lives.

In Hiran, a region in mid-Somalia, there was a considerably higher level of armed conflict as there was no single dominating militia. Several clan and sub-clan militias continued to fight each other.$^{50}$ Local Sharia courts, supporting their own militias, added to the violence rather than providing any political stability. Additionally, banditry was widespread and reflected the state and lawlessness of the region. ${ }^{51}$

The Southern region of Bay, too, was recognised by widespread lawlessness. Although the militia group Rahanweyn Resistance Army (RRA) had set up some reasonable functioning regional administration in 2002, disagreement within this militia led to its complete disintegration into several factions. ${ }^{52}$ These factions were not only fighting each other, but also deliberately targeting civilians, relaying landmines and involved in outright banditry. ${ }^{53}$ As a consequence, the RRA factions were by no means interested and able to provide the region with a stable and successful administration..$^{54}$

Mogadishu, the capital of Somalia, was and remains the most insecure region of Somalia. In this region, public goods and services have been absent for the longest period of time. International aid organisations have consistently tried to compensate for this lack. Yet, as Mogadishu's sea and airport remained closed in 2003, humanitarian interventions were extremely difficult, dangerous and costly. ${ }^{55}$ At the same time, the city hosted an estimated 150,000 internally displaced persons many of whom had been there for over a decade..$^{56}$ Banditry and violent crime reflected Mogadishu's lawlessness even when inter-militia fighting calmed down. The Transitional Government appointed at the Eldoret Conference to re-establish Somalia as a state, never even came close to controlling the capital.

Although we agree with Menkhaus' statement that: 'Somalia is a failure among failed states', the picture of Somalia in 2003 showed that particular regions displayed less features of state collapse than others. ${ }^{57}$ This is mainly due to the fact that certain regions were more peaceful and under control by an accepted local authority. Following this logic, we consider Somaliland as the area, which is least collapsed on a local level, followed by Puntland. In Kismayo and Hiran, state-like structures are much weaker; and finally, Bay and Mogadishu are considered to be the most failed regions. However, although this variation in state failure is shown in our description of Somalia, so far it lacks empirical support.

\section{FROM MACRO- TO MICRO-LEVEL INDICATORS}

Before we can start showing this micro-level variation in state failure with empirical data, we have to identify indicators that measures the concept of state failure on the ground. In this identification process, we attempt to bridge the gap between the academic community who treats state failure as a macro-level concept and the practioners who are working in the field and see micro-level variations across regions. In doing so, we focus on the role of combatants and armed groups because 
they have to be engaged in any initiative to build up the state of Somalia, and the ability of local authorities to provide public goods and services.

When a state fails and armed conflict and violent crime take place, we expect to find the presence of armed groups in that country. As described in the case of Somalia, the number of such groups plays a crucial role in the stability of the region. ${ }^{58}$ In addition, we presume that in contrast to soldiers serving a stable state, the members of armed groups within a failed state are likely to possess extensive combat experience. ${ }^{59}$ The more severe a region is failed, the more combat experience individual fighters will have. Moreover, we expect to find very low percentage of female fighters in those areas that are fully collapsed because of the regular combat activities and the ad hoc nature of the structure of such groups. For Somalia, it is also known that the widow of a deceased fighter traditionally inherits the former fighter's position. While currently fighting militia groups will not be capable of fulfilling this social responsibility of caring for dependants of former fighters, we expect groups in more stable regions to take over this duty. ${ }^{60}$

Not only do we expect variation in state failure to reflect differences in the number of armed groups, combat experience and variation in the female-male balance, but we also expect variation in state failure to be depicted by differences in the motivation of combatants. A regular soldier that joins the national army in a stable country might join in order to have secure employment or for more idealistic reasons, like the wish to support the state or defend democracy. However, we assume that Somali combatants will have a variety of different motives to join armed groups. ${ }^{\circ 1}$ These include the expectation to make a living or the desire to uphold law and order as well as the wish to take revenge or simply to defend oneself.

Until now, we have focused on those micro-level state failure indicators that reflect the linkage between armed conflict and state failure. However, we also have argued that an essential element of state failure is the absence of a central authority that provides public goods and services. Most macro-level aggregated state failure indices, like those discussed above, try to measure this by looking at economic factors, such as having a low GDP and little recorded international trade. ${ }^{62}$ On the microlevel, we expect to observe flourishing grey and black markets, providing both daily necessities as well as illegal goods. Often these markets are awash with small arms and narcotic drugs. The macro-level linkage between drugs, conflict and state failure has been extensively studied. ${ }^{63}$ Therefore, we also expect to see elevated levels of drug consumption in the failed Somali regions.

Besides the existence of grey and black markets, we presume that failed states like Somalia are also unable to provide public goods like education and health care. That is to say, in regions, which we consider more failed, we expect lower levels of education and personal health. ${ }^{64}$ Additionally, we expect that the more regions are failed, the more citizens experience authorities to be highly corrupt and to be taking part in extorting goods and services. Thus, citizens display a general disbelief in the benevolence of authorities and are in turn unwilling to fulfil civic duties. $^{65}$ 


\section{DATA AND METHOD}

To show that these micro-level indicators of state failure vary across the Somali regions, we make use of a study which was conducted as a part of a preparatory exercise for a Disarmament, Demobilisation and Reintegration program (DDR) in Somalia following the Somali National Reconciliation Conference in 2003. At the time, seven Somali regions were selected for interviewing on the basis of their high level of active military personnel: the regions of Somaliland and Puntland in the North of Somalia, the region Bay and Hiran in mid-Somalia, Mogadishu North and South as well as Kismayo in the South of Somalia. In our analysis, Mogadishu North and South are combined.

In every region, several hundred interviews were held with combatants from as many factions and militias as possible. The respondents were interviewed between August and December 2003. Random sampling could not be applied in this study due to security and logistic reasons and respondents were selected by the armed group itself. ${ }^{66}$ Only one faction refused to take part in the survey. The questionnaire was developed in English by an interdisciplinary team consisting of Somali and international experts. Back-translation was used to ensure linguistic and cultural adequacy.

The respondents were interviewed in a place that provided as much privacy as possible, e.g. in a separate room. Every participant was informed before the interview about the purpose and method of interview and was reassured confidentiality and the possibility to discontinue the interview at any time without negative repercussions. Five hundred and eighty-seven respondents were excluded from the analysis because they denied their consent after being informed about the purpose of this study or during the interview. Another 12 were excluded because the interviews did not fulfil the minimal standards (a minimum of 10 interviews per interviewer was required). As a result, the answers of 8,124 respondents were used in the statistical analysis. This number represents approximately 11 per cent of the total estimated number of combatants in Somalia in 2003. ${ }^{67}$

The respondents were assigned to the categories of armed groups through expert rating. Out of the 8,124 respondents, 4,638 (57 per cent) belonged to regional authorities (such as the Somaliland National Forces), 1,722 (21 per cent) to warlord militias (such as the Rahanweyn Resistance Army), 481 (6 per cent) belonged Sharia court militias (such as the Hiran Court Forces) and 78 (1 per cent) were members of business militias; 1,090 (13 per cent) combatants were members of other militias and 115 ( 1 per cent) of the respondents could not be assigned to any of these groups with certainty.

A total of 3,903 (48 per cent) respondents were from Somaliland, 854 (10 per cent) came from Puntland, 604 (7 per cent) from Bay, 1,468 (18 per cent) from Mogadishu, 599 (7 per cent) from Kismayo and 696 (8 per cent) from Hiran. In our sample of 8,124 combatants, we included 882 women and 7,242 men. On average, the respondents were around 37 years old (mean 37.3) and were married (67 per cent). Less than half of them had completed primary education (44 per cent) and 
even less had received any vocational training (23 per cent). About two-thirds of our sample (65 per cent) reported combat experience.

We calculated proportions per region in percentages. Since the sample consists of six independent convenience samples, we did not correct for differences in sample size, i.e. the percentages remain unweighted. We tested the significance of the reported differences per region running $\chi^{2}$ tests on a one per cent alpha level. Where results were significant, we employed Cramer's V to estimate the nominal association between the variables independent of the sample size. ${ }^{68} \mathrm{We}$ consider any Cramer's V greater than 0.2 worth noticing; any value above 0.3 reflects a meaningful strength of association; and any value above 0.5 reveals a strong relationship between the variable region and our micro-level indicators of state failure.

\section{ANALYSIS}

First, we analyse the possible regional differences concerning basic sociodemographic variables, such as age, gender, combat experience and health complaints (an overview of these micro-level social-demographic variables is given in Table 1). Thereafter, we devote our attention to the differences in motivation for joining an armed group and look at the different types of armed groups.

We can observe a distinct pattern of varying gender-ratios per region. Females are more likely to be involved in an armed group active in those regions that are less failed. These particular armed groups often develop into regional authorities that provide public services and are less involved in fighting. In such groups, females are more likely to be included as they traditionally are not allowed to take part in combat operations. Furthermore, a Somali custom is that widows inherit the position of their passed-away husbands within the forces. Hence, we find 85 per cent of all female respondents to belong to regional authorities, most of which are found in Somaliland (Somaliland National Forces). In contrast, only one per cent of the participating females belong to Sharia militias and none are members of any business militia. These particular militias are especially present in the more failed regions of Hiran and Mogadishu.

The mean age of those interviewed also differs per region. We assumed that older combatants are especially those who were active in less failed regions of Somalia. This picture is confirmed by the analysis, which indicates that age indeed reflects the more settled armed groups, which are in particular found in Somaliland and Puntland. However, the region of Hiran forms an exception. Combatants in this region are older than those in the regions of Puntland and Kismayo. This might be explained by the high percentage of Sharia militia (66 per cent), which tend to attract older members, in the region. Respondents belonging to the Sharia militia had a mean age of 37 years, compared to the mean age of 33 years of the three categories of warlord, business and other militias. Regional militia on the other hand had a mean age of 40 years, which again supports the idea that age reflects whether a group can be found in more or less stable parts of the country. 
TABLE 1

DISTRIBUTION OF SOCIO-DEMOGRAPHIC INDICATORS PER SOMALI REGION

\begin{tabular}{lcccccccc}
\hline & Somalil. & Puntl. & Kismayo & Hiran & Bay & Mogadishu & Total & Cr's V \\
\hline \% Female & $17.2 \%$ & $10.1 \%$ & $9.5 \%$ & $2.3 \%$ & $2.5 \%$ & $2.5 \%$ & $10.9 \%$ & $0.21 * * *$ \\
Mean age & 41.3 & 37.0 & 34.0 & 39.6 & 30.5 & 29.7 & 37.3 & - \\
Primary education & $49.2 \%$ & $38.8 \%$ & $62.9 \%$ & $34.3 \%$ & $32.5 \%$ & $37.2 \%$ & $44.5 \%$ & $0.17 * * * *$ \\
Combat experience & $48.4 \%$ & $82.1 \%$ & $43.1 \%$ & $84.1 \%$ & $100 \%$ & $85.0 \%$ & $65.1 \%$ & $0.41 * * *$ \\
Somatic complaints & $12.7 \%$ & $25.5 \%$ & $25.7 \%$ & $40.7 \%$ & $28.6 \%$ & $30.2 \%$ & $78.3 \%$ & $0.22 * * * *$ \\
Mental health complaints & $2.2 \%$ & $1.8 \%$ & $9.7 \%$ & $6.3 \%$ & $2.5 \%$ & $16.3 \%$ & $5.6 \%$ & $0.24 * * *$ \\
Cannabis consumption & $15.3 \%$ & $18.3 \%$ & $90.8 \%$ & $76.1 \%$ & $89.7 \%$ & $62.4 \%$ & $40.4 \%$ & $0.62 * * *$ \\
\hline
\end{tabular}

Note: $* * *$, the results are statistically significant on a $p<0.001$ (i.e. highly significant). 
The varying age structure of respondents might be related to their level of education, i.e. older participants might have joined the armed group later and spend more time on education. However, 42 per cent of the participants reported that they had no education at all, while 13 per cent had only attended Koranic school, 32 per cent had completed primary and 11 per cent secondary school. Only one per cent had a university degree. Furthermore, 25 per cent had received vocational training.

A similar argument can be made when looking at the regional difference concerning combat experience. Less failed Somali regions will experience less violence. On the microlevel, we should, therefore, find fewer respondents, who have combat experience. This is confirmed by the analysis; we find an association of Cramer's V of 0.41 between regions and combat experience. The high percentage of respondents with combat experience in Puntland is most likely caused by the border clashes with Somaliland. Indeed, of those respondents from Puntland who have combat experience 83 per cent are from Gaalkacyo, the district where fighting took place in 2003. Furthermore, the fighting between the factions of the RRA factions in Bay is reflected by the data; all respondents in Bay have experienced combat.

Concerning health, we assumed that less failed regions in Somali were less troubled by health problems than those that were collapsed. To look at the association between the regions and health, we focused on those variables that reflected somatic complaints and mental health. ${ }^{69}$ About one-fourth of the Somali combatants reported that they had a cough, headache, fever, constipation, diarrhoea, a skin rash, hypertension and/or physical pain within the four weeks preceding the interview. A much smaller percentage, 6 per cent, reported psychological symptoms typical for a post-traumatic stress disorder. The linkage between mental health problems and the more failed Somali regions is present but is not very strong. The Cramer's V association between the regional variable and somatic complaints is 0.22 and between the region and mental health is 0.24 .

Additionally, we focused on the availability of substances and drug-taking habits of the Somali combatants. We assumed that failed Somali regions have more narcotic drugs available and combatants in these particular regions will use more such drugs than those combatants in the less failed regions. We probed for the following substances: khat, hash, alcohol and banji seeds. Note that khat is a legal substance in Somalia, while the narcotic drugs, as well as alcohol can be considered 'illegal' or culturally unaccepted. Furthermore, participants were asked about the habits in their localities of sniffing substances, like glue or petrol thinner, or taking tablets to get high. Overall, we observe stark regional variation for all narcotic substances, while the consumption of khat is almost equally high for all regions. About 15 per cent of the combatants interviewed in Somaliland report that cannabis is consumed in their locality, while 62 per cent of the combatants from Mogadishu and as many as 91 per cent of the combatants from Kismayo have observed this habit. The very high percentage for Kismayo could be a result of drugs being imported through its port. Furthermore, the United Nations Office for Drug Control at the time suspected large quantities of marijuana being grown in areas close to Kismayo and Bay. ${ }^{70}$ This would also explain the very high percentage for Bay ( 90 per cent). The analysis concerning 
the consumption of narcotic drugs reflects the variation in state failure across Somali regions. The less power an authority is able to project, the less control they have over markets and the more illegal goods are available and used.

This presents a twofold challenge to any state building initiative in Somalia. Our findings indicate the existence of large markets for illegal goods. These markets include cross-border trading and can be an outlet for international crime. Those Somali, who profit from this crime, will most likely oppose any efforts to revive a strong state, fearing that such a state would put an end to their business. Furthermore, narcotic drugs can be a source of income for militia groups fostering a continuing cycle of violence. ${ }^{71}$

Additionally, our analysis showed that drugs are not only traded but they are also consumed widely within units of the Somali armed groups. Substance-dependent combatants will be more difficult to re-integrate into society than their healthy counterparts. ${ }^{72}$ This is of course also true for combatants who are using traditional substances such as khat. $^{73}$

Not only did we assume differences across region when looking at combat experience, but we also presumed difference in motivation to join Somali armed groups (an overview of micro-level variables related to armed conflict is given Table 2). Respondents were asked why they joined the respective armed group and were offered several answer categories from which they could choose as many as they thought were applicable. For the categories 'to make an income', 'to defend myself', 'to re-establish law and order' and 'to protect my family' we find major regional differences. In Somaliland, for example, 51 per cent of the participants reported that they joined to make an income. This reflects the relative stable nature of the forces in Somaliland, which employ soldiers just as a regular state army would do. Regions that do not have such forces also have a substantially smaller percentage of combatants citing employment as their motivation to join (Puntland 8 per cent, Kismayo 7 per cent, Hiran 9 per cent and Bay close to 0 per cent).

The exception forms the Mogadishu region. In this region, 24 per cent of the combatants name income as one of their motivations. This relatively high percentage can be explained by the so-called Kalashnikov-lifestyle. This term refers to combatants, who have grown up in a failed state and are accustomed to surviving by using force. ${ }^{74}$ They take whatever they need using their weapon and are under constant threat of being attacked by rival armed groups. Although the Kalashnikovlifestyle might partly explain this high percentage, the picture is even more complex when looking at the percentage of combatants that join their respective armed groups for the motivation to uphold law and order. About the same percentage of combatants in Somaliland and Mogadishu (18 per cent) indicate this motivation.

This particular percentage might also be explained the desire to make one's environment more safe and predictable. To investigate this aspect, we looked at the answers given by the respondents on the question to whom they would turn for support, if others physically threatened them or their families. Again the Somali combatants could choose different response categories. In this article, we only report the results for 'would turn to local authorities' and 'would defend myself or my 
TABLE 2

DISTRIBUTION OF CONFLICT VARIABLES PER SOMALI REGION.

\begin{tabular}{|c|c|c|c|c|c|c|c|c|}
\hline & Somalil. (\%) & Puntl. (\%) & Kismayo $(\%)$ & Hiran $(\%)$ & Bay $(\%)$ & Mogadishu (\%) & Total $(\%)$ & Cr's V \\
\hline \multicolumn{9}{|c|}{ Reason for joining (multiple answers permitted) } \\
\hline - Income & 51.4 & 8.0 & 7.1 & 9.1 & 0.3 & 24.0 & 49.9 & $0.31 * * * *$ \\
\hline - Self-defence & 28.7 & 16.4 & 9.8 & 8.3 & 13.8 & 22.9 & 47.0 & $0.41 * * *$ \\
\hline - Law \& order & 18.1 & 33.6 & 10.2 & 16.5 & 3.2 & 18.4 & 16.9 & $0.40 \% * \%$ \\
\hline - Protect family & 15.5 & 23.6 & 19.0 & 6.6 & 13.1 & 22.2 & 16.8 & $0.35 * * 2$ \\
\hline \multicolumn{9}{|l|}{ Type of armed group } \\
\hline - Regional authority & 98.3 & 27.9 & 93.6 & 0.1 & 0 & 1.1 & 57.9 & $0.57 * * *$ \\
\hline - Sharia militia & 0 & 0 & 0 & 66.2 & 0 & 1.4 & 5.9 & \\
\hline - Warlord militia & 0.9 & 34.3 & 1.0 & 4.2 & 97.7 & 52.4 & 21.2 & \\
\hline - Business militia & 0 & 0 & 0 & 0 & 0 & 5.3 & 1.0 & \\
\hline - Other & 0.8 & 37.0 & 5.3 & 27.7 & 1.2 & 34.9 & 13.4 & \\
\hline - Missing & 0.3 & 1.1 & 0.7 & 1.7 & 1.2 & 5.0 & 1.4 & \\
\hline \multicolumn{9}{|l|}{ Response to physical threat } \\
\hline - Report to authorities & 90.5 & 91.9 & 52.8 & 60.1 & 64.7 & 7.2 & 68.3 & $0.51 * *$ \\
\hline - Self-defence & 2.0 & 2.7 & 15.0 & 16.1 & 4.5 & 54.6 & 13.9 & \\
\hline - Other & 17.8 & 7.5 & 5.6 & 32.2 & 23.8 & 30.8 & 38.2 & \\
\hline
\end{tabular}

Note: $* * * *$, the results are statistically significant on a $p<0.001$ (i.e. highly significant). 
family would defend me'. In Somaliland, 90 per cent of the respondents would turn to local authorities for help, if they felt threatened. In Puntland, this percentage is even slightly higher with 92 per cent. The percentages decrease significantly when looking at regions further South. In Kismayo, Hiran and Bay, respectively 53, 60 and 65 per cent, would turn to local authorities when physically threatened. These percentages are rather high compared to the 7 per cent of the Somali respondents who are living in the Mogadishu region. Consequently, this picture is reversed for those respondents, who would employ self-defence or who would expect their family to defend them.

These results confirm our assumptions; in the more failed Somali regions, combatants are less willing to grant local authorities the monopoly of violence than those living in the more stable regions. As we have seen, this is probably motivated by the (often very realistic) perception that such authorities do not exist or are dysfunctional.

To look more into the kind of authorities and whether they vary per Somali region, we calculated Cramer's V. We found a very high association of 0.57 , between the type of militia and region they are located in. We were particularly interested in how many combatants were members of regional authorities in a specific region. We assume that the more people are a member of such authorities, the less failed a region is. The results are mixed. In Somaliland, 98 per cent of the respondents belonged to such an authority, in Puntland 27 per cent, in Kismayo 93 per cent, in Hiran only 0.1 per cent, in Bay none of the respondents belonged to a regional authority and in Mogadishu only one per cent. The high percentage found for Kismayo can be explained by the existence of the Juba Valley Alliance. Although this armed group contributes to local stability as an occupying force, it does not seem to be part of a wider state-like structure. Also Puntland does not follow the expected pattern. This might be the case, because many of the respondents from Puntland, were interviewed close to the border, where the described hostilities took place. This again highlights that though Puntland can be considered less failed than other parts of Somali, it was by 2003 by no means a functional state.

In general, the analysis of the micro-level state failure indicators has shown that the Somali regions indeed vary significantly. However, Cramer's V is low for some associations. This is probably because no Somali region resembles a truly stable state. Even Somaliland, which is often described as a success in statebuilding represents at best a weak state. ${ }^{75}$

\section{DISCUSSION AND CONCLUSION}

The number of international interventions in name of statebuilding underscores the need to develop an exact understanding of state failure. Academics and practitioners alike are still debating what constitutes and leads to this phenomenon. In doing so, they have primarily focused on the linkage between state failure and armed conflict within the countries. Although, we do not deny that this linkage is an important feature and cause of state failure, we expand this definition by also looking at the 
provision of public goods and services. As long as a state is able to provide these goods and service, we consider it as less failed.

This focus on the provision of public goods and services and the problems that we have with relying on highly aggregated indicators to determine state failure, led us to a new way of examining the causes and consequences of it. We argue that scholars and practitioners have failed to empirically examine the varying degrees of state failure across regions. Some regions are less failed than others. For example, some regions in a failed state are relatively stable since they are under control of an armed group that provide citizens with public goods and service.

With the help of a unique data-set collected in Somalia in 2003, we examine quantitatively these micro-level variations of state failure. Somalia is a country that has been considered as fully collapsed since the early 1990s. However, it is also a country with stark differences across regions. In 2003, the North of Somalia, regions such as Somaliland and Puntland were relatively functioning. The two regions Bay and Hiran, in contrast, were characterised by a lack of public goods and services and sometimes experienced major outbursts of violence. The most Southern regions of Mogadishu and Kismayo were considered to be fully collapsed regions that are characterised by insecurity and violence.

To test this variance in state failure quantitatively, we use a data-set that included more than 8,000 active Somali combatants who were questioned about their personal situation and environment. As such, the data-set allows us to determine whether there is a strong association between the defined micro-level indicators and the variation of state failure in the Somali regions. Our analysis shows that there are indeed large and significant regional differences concerning the structure of and membership in different types of armed groups, reasons to join these groups, trust or mistrust in local authorities and habits of substance consumption. Furthermore, there are smaller, but significant, variations regarding levels of education as well as somatic and mental health. All these variations show that the Northern part of Somali, especially Somaliland and Puntland are less failed than those regions in the South, such as the region surrounding Mogadishu and Bay.

We are not the first to observe that there is local variation within failed states. For Somalia, the United Nations have repeatedly pointed out this fact. ${ }^{76}$ However, most of the existing studies that indicate these micro-level variations in state failure have primarily relied on case descriptions. To our knowledge, no study exists that has tried to measure these variations quantitatively. This is mainly due to lack of valid and reliable micro-level data that tap the different features of state failure. We, therefore, consider this study as both unique and highly relevant since we quantitatively confirm that micro-level data are indispensable to understand key players within failed states.

Without doubt there are limitations to this study and room for improvement and further research. One of our main concerns is that the data-set used in this study is based on six convenient samples, which makes inference outside the sample problematic. It might be the case that respondents were chosen by their commanders on the basis of their views on the conflict. Equally, they could have prevented 
combatants, that they saw unsuitable for interviewing, for example those who are known to consume large amounts of substances or child combatants, from taking part in the survey. ${ }^{77}$ However, the response given by the respondents are clearly not always socially desirable given the cultural context. For example, many reported the widespread consumption of alcohol within their localities, even though this is forbidden by religious and customary law. ${ }^{78}$ In addition, our analysis confirms variance of state failure on the microlevel using a rather conservative method of measuring association (Cramer's V).

This study is a first step to disentwine the concept of state failure by examining its microlevel correlates. In this article, we then also do not argue to abandon macrolevel data. Instead, we advocate for the need to integrate data of different levels of analysis to understand state failure and its causal mechanisms. Only then can we grasp the dynamic nature of the phenomenon and develop successful state building interventions.

\section{ACKNOWLEDGEMENTS}

We wish to acknowledge Dr Harald Hinkel's vital role in gathering the data. Without his tireless work and expertise, this research would have been impossible. We equally acknowledge and thank Dr Elisabeth Schauer and all our colleagues from vivo international, who were involved in data collection and provided their support both in Somalia and Germany. We thank all Somalia enumerators and above all the participants in this study.

\section{NOTES}

1. Robert Bates, When Things Fell Apart: State Failure in Late-Century Africa (New York: Cambridge University Press 2008); Branwen Gruffydd Jones, 'The Global Political Economy of Social Crisis: Towards a Critique of the "Failed State" Ideology', Review of International Political Economy 15 (2008) pp.180-205; Robert Rotberg, 'Failed States in a World of Terror', Foreign Affairs 81 (2002) pp.127-40; Robert Rotberg, 'The New Nature of Nation-State Failure', The Washington Quarterly 25 (2002) pp.85-96.

2. Zaryab Iqbal and Harvey Starr, 'Bad Neighbors: Failed States and Their Consequences', Conflict Management and Peace Science 25 (2008) pp.315-31; Peter Tikuisis, 'On the Relationship between Weak States and Terrorism', Behavioral Sciences of Terrorism and Political Aggression 1 (2009) pp.66-79; James A. Piazza, 'Incubators of Terror: Do Failed and Failing States Promote Transnational Terrorism?', International Studies Quarterly 52 (2008) pp.469-88; Edward Newman, 'Weak States, State Failure, and Terrorism', Terrorism and Political Violence 19 (2007) pp.463-88; Princeton N. Lyman and Stephen J. Morrison, 'The Terrorist Threat in Africa', Foreign Affairs 83 (2004) pp.75-86; Stephan Krasner and Carlos Pascual, 'Addressing State Failure', Foreign Affairs 84 (2005) pp.153-63.

3. Rotberg, 'Failed States in a World of Terror' (note 1); Derick W. Brinkerhoff, 'Rebuilding Governance in Failed States and Post-Conflict Societies: Core Concepts and Cross-Cutting Themes', Public Administration and Development 25 (2005) pp.3-14; Pierre Englebert and Denis M. Tull, 'Postconflict Reconstruction in Africa: Flawed Ideas About Failed States', International Security 32 (2008) pp.106-39.

4. Tobias Debiel, Rainer Glassner, Conrad Schetter and Ulf Terlinden, 'Local State-Building in Afghanistan and Somaliland', Peace Review 21 (2009) pp.38-44; Tobias Debiel and Daniel Lambach, 'How State-Building Strategies Miss Local Realities', Peace Review 21 (2009) pp.22-8; Monika Francois and Inder Sud, 'Promoting Stability and Development in Fragile and Failed States', Development Policy Review 24 (2006) pp.141-60.

5. John Heathershaw and Daniel Lambach, 'Introduction: Post-Conflict Spaces and Approaches to Statebuilding', Journal of Intervention and Statebuilding 2 (2008) pp.269-90. 
6. Englebert and Tull (note 3).

7. Jutta Bakonyi, 'Between Protest, Revenge and Material Interests: A Phenomenological Analysis of Looting in the Somali War', Disasters 34 (2010) pp.238-55; Matt Bryden, 'No Quick Fixes: Coming to Terms with Terrorism, Islam, and Statelessness in Somalia', The Journal of Conflict Studies 23 (2003) pp.24-56.

8. UN, Assistance for Humanitarian Relief and the Economic and Social Rehabilitation of Somalia (New York: United Nations General Assembly 2003).

9. Christopher Clapham, 'Degrees of Statehood', Review of International Studies 24 (1998) pp.143-57; Christopher Clapham, 'The Challenge to the State in a Globalized World' in Jennifer Milliken and Keith Krause (eds) State Failure, Collapse \& Reconstruction (Oxford: Blackwell Publishing Limited 2003) pp.25-44; Paul Kingston, 'States-within-States: Historical and Theoretical Perspectives' in Paul Kingston and Ian Spears (eds) States-within-States: Incipient Political Entities in the Post-Cold War Era (New York: Palgrave Macmillan 2004) pp.1-13; Shahar Hameiri, 'Failed States or a Failed Paradigm? State Capacity and the Limits of Institutionalism', Journal of International Relations and Development 10 (2007) pp.122-49.

10. Tobias Hagmann and Markus von Hoehne, 'Failed State or Failed Debate? Multiple Somali Political Orders within and Beyond the Nation State', Politorbis 42 (2008) pp.20-6.

11. Debiel et al. (note 4); Debiel and Lambach (note 4).

12. Brennan M. Kraxberger, 'Failed States: Temporary Obstacles to Democratic Diffusion or Fundamental Holes in the World Political Map?', Third World Quarterly 28 (2007) pp.1055-71; Martin Doornbos, 'State Collapse and Civil Conflict and External Intervention' in Peter J. Burnell and Vicky Randall (eds) Politics in the Developing World (Oxford: Oxford University Press 2008) pp.250-67.

13. Sven Chojnacki, Max Grömping and Michael Spies, Armed Conflict Beyond the State - Spatial and Temporal Patterns of Non-State Violence in Somalia, 1990-2007, Paper presented at the Joint CSCW WG3/GROW-Net workshop: Environmental Conflicts and Conflict Environments, 2009; Neil A. Englehart, 'Governments Against States: The Logic of Self-Destructive Despotism', International Political Science Review/Revue Internationale de Science Pol 28 (2007) pp.133-53; Daniel Lambach, 'Warum Kollabieren Staaten? [Why Do States Collapse?]', Politische Vierteljahresschirft 43 (2009), pp.235-55.

14. See for an overview Edward Newman, 'Failed States and International Order: Constructing a PostWestphalian World', Contemporary Security Policy 30 (2009) pp.421-43.

15. Pauline Baker, The Conflict Assessment System Tool (Cast) - An Analytical Model for Early Warning and Risk Assessment of Weak and Failing States (Washington, DC: The Fund for Peace 2006).

16. Daniel Esty, Jack A. Goldstone, Ted Gurr, Pamela Surko and Alan Unger, Working Papers: State Failure Task Force Report (McLean, VA: Science Applications International Corporation 1995).

17. Lisa Anderson, 'Antiquated Before They Can Ossify: States That Fail Before They Form', Journal of International Affairs 58 (2004) pp.1-16.

18. Newman (note 14); Stefan Borg and Leonardo Figueroa-Helland, 'The Lure of State Failure Critical Engagements with State Failure Discourse in World Politics' in Annual Meeting of the Theory vs. Policy? Connecting Scholars and Practitioners (New Orleans, LA: New Orleans Hilton Riverside Hotel, The Loews New Orleans Hotel 2010).

19. Englehart (note 13); P. Bilgin and A. D. Morton, 'Historicising Representations of "Failed States": Beyond the Cold-War Annexation of the Social Sciences?', Third World Quarterly 23 (2002) pp.5580; Stewart Patrick, "Failed" States and Global Security: Empricial Questions and Policy Dilemmas', International Studies Review 9 (2007) pp.644-62.

20. Englehart (note 13) p.135.

21. Baker (note 15); Halvard Buhaug, 'Relative Capability and Rebel Objective in Civil War', Journal of Peace Research 43 (2006) pp.691-708; James Fearon and David Laitin, 'Ethnicity, Insurgency, and Civil War', American Political Science Review 97 (2003) pp.75-90; Richard Jackson, 'The State and Internal Conflict', Australian Journal of International Affairs 55 (2001) pp.65-81; Borg and Figueroa-Helland (note 18).

22. Charles T. Call, 'The Fallacy of the "Failed State"', Third World Quarterly 29 (2008) pp.1491-507.

23. Lambach (note 13) p.237.

24. Robert Bates, 'The Logic of State Failure: Learning from Late-Century Africa', Conflict Management and Peace Science 25 (2008) pp.297-314; Robert Bates, Avner Greif and Smita Singh, 'Organizing Violence', Journal of Conflict Resolution 46 (2002) pp.599-628.

25. Lambach (note 13) pp.239-40. 
26. Stergios Skaperdas, 'Restraining the Genuine Homo Economicus: Why the Economy Cannot Be Divorced from Its Governance', Economics \& Politics 15 (2003) pp.135-62; Bates et al., 'Organizing Violence' (note 24).

27. Englehart (note 13) p.134; William Reno, 'The Politics of Insurgency in Collapsing States', Development and Change 33 (2002) pp.837-58.

28. Francis Fukuyama, 'The Imperative of State-Building', Journal of Democracy 15 (2004) pp.17-31.

29. Francois and Sud (note 4) p.143.

30. Stuart E. Eizenstat, John Edward Porter and Jeremy M. Weinstein, 'Rebuilding Weak States', Foreign Affairs 84 (2005) pp.134-46; Robert Rotberg, 'Failed States, Collapsed States, Weak States: Causes and Indicators' in Robert Rotberg (ed.) State Failure and State Weakness in a Time of Terror (Cambridge: World Peace Foundation; Brookings Institution Press 2003) pp.1-25.

31. Clapham, 'Degrees of Statehood' (note 9) p.143.

32. Anthony Vinci, 'Anarchy, Failed States, and Armed Groups: Reconsidering Conventional Analysis', International Studies Quarterly 52 (2008) pp.295-314.

33. Kingston (note 9) p.6.

34. Clapham, 'Degrees of Statehood' (note 9); Clapham, 'The Challenge to the State in a Globalized World' (note 9); Hameiri (note 9).

35. Susan Rice and Stewart Patrick, Index of State Weakness in the Developing World (Washington, DC: The Brookings Institution 2008).

36. Robert Rotberg, 'The Failure and Collapse of Nation-States: Breakdown, Prevention and Repair' in Robert Rotberg (ed.) When States Fail: Causes and Consequences (Princeton, NJ: Princeton University Press 2004) pp.1-49.

37. Bryden (note 7) p.25; UNSC, Report of the Secretary-General on the Situation in Somalia S/2003/231 (New York: United Nations Security Council 2003); International Crisis Group, 'Negotiating a Blueprint for Peace in Somalia', Africa Report 59 (Nairobi: International Crisis Group 2003).

38. World Bank, Conflict in Somalia: Drivers and Dynamics (New York: World Bank 2005).

39. Ioan Lewis, Understanding Somalia and Somaliland: Culture, History, Society (New York: Columbia University Press 2008).

40. Kenneth Menkhaus, Somalia: State Collapse and the Threat of Terrorism (Oxford: Oxford University Press for the International Institute for Strategic Studies 2004).

41. Kenneth Menkhaus, Somalia: A Situation Analysis and Trend Assessment (Geneva: UNHCR 2003); UNSC, Report of the Panel of Experts on Somalia Pursuant to Security Council Resolution 1425 (2002) (New York: United Nations Security Council 2003).

42. Ibid.

43. UN (note 8); UNICEF, 'Unicef Somalia Review Nov/Dec 2003', UNICEF Somalia Review (Washington, DC: UNICEF 2003); UNSC, 4718th Meeting (Pm) Security Council (New York: United Nations Security Council 2003).

44. Hagmann and von Hoehne (note 10); Nat J. Colletta and Michelle L. Cullen, Violent Conflict and the Transformation of Social Capital: Lessons from Cambodia, Rwanda, Guatemala, and Somalia (Washington, DC: World Bank 2000); Bakonyi (note 7).

45. Hagmann and von Hoehne (note 10) p.24.

46. UNSC (note 37).

47. UNSC (note 41).

48. IRIN, 'Somalia: Drugs Destroyed in Mogadishu' in Humanitarian News and Analysis, 27 Aug. (New York: OCHA 2002), online at $<$ http://www.irinnews.org/report.aspx?reportid=33945>.

49. Menkhaus (note 40); International Crisis Group (note 37).

50. UNICEF, 'Unicef Somalia Review Feb 2003', UNICEF Somalia Review (Washington, DC: UNICEF 2003), online at <http://www.reliefweb.int/rw/rwb.nsf/db900sid/OCHA-64DHAT?OpenDocument\&query=somalia\%20review $>$.

51. Menkhaus (note 41).

52. International Crisis Group (note 37); International Crisis Group, 'Salvaging Somalia's Change for Peace', Africa Report No 11 (Nairobi: International Crisis Group 2002); IRIN, 'Somalia: Over 20 Killed in Fresh Fighting in Baidoa' in Humanitarian News and Analysis, 4 Jul. (New York: OCHA 2002), online at $<$ http://www.irinnews.org/report.aspx? reportid=32832>.

53. Menkhaus (note 41)

54. International Crisis Group (note 37); UNSC (note 41).

55. UNSC (note 37).

56. UN (note 8). 
57. Menkhaus (note 40) p.17.

58. Chojnacki et al. (note 13).

59. Ibid.

60. Michael Odenwald, Harald Hinkel and Elisabeth Schauer, 'Challenges for a Future Reintegration Programme in Somalia: Outcomes of an Assessment on Drug Abuse, Psychological Distress and Preferences for Reintegration Assistance', Intervention - International Journal of Mental Health, Psychosocial Work and Counselling in Areas of Armed Conflict 5 (2007) pp.109-23.

61. For more information on the motivation of combatants see: Ana Arjona and Stathis Kalyvas, Preliminary Results of a Survey of Demobilized Combatants in Columbia (Yale: Yale University 2006); Roos Haer, The Management of Armed Groups. Constraining Human Right Abuses in the Democratic Republic of the Congo, Paper presented at the 10th Dutch Political Science Association Meeting, Leuven (2010, May).

62. Baker (note 15); Esty et al. (note 16); Newman (note 14); Rice and Patrick (note 35).

63. Svante E. Cornell, 'The Interaction of Narcotics and Conflict', Journal of Peace Research 42 (2005) pp.751-60; Cornelius Graubner, Drugs and Conflict - How the Mutual Impact of Illicit Drug Economies and Violent Conflict Influences Sustainable Development, Peace and Stability (Eschborn: German Technical Cooperation 2007).

64. Newman (note 14) p.431.

65. Brinkerhoff (note 3); Vanessa Ruget and Burul Usmanalieva, 'The Impact of State Weakness on Citizenship a Case Study of Kyrgyzstan', Communist and Post-Communist Studies 40 (2007) pp.441-58.

66. Michael Odenwald, Harald Hinkel, Elisabeth Schauer, Frank Neuner, Maggie Schauer, Thomas Elbert and Brigitte Rockstroh, 'The Consumption of Khat and Other Drugs in Somali Combatants: A Cross-Sectional Study', PLoS Medicine 4 (2007) e341.

67. Michael Odenwald, Harald Hinkel, Elisabeth Schauer, Maggie Schauer, Thomas Elbert, Frank Neuner and Brigitte Rockstroh, 'Use of Khat and Posttraumatic Stress Disorder as Risk Factors for Psychotic Symptoms: A Study of Somali Combatants', Social Science \& Medicine 69 (2009) pp.1040-48.

68. William H. Press, Numerical Recipes the Art of Scientific Computing (Cambridge: Cambridge University Press 2007)

69. Michael Odenwald, Birthe Lingenfelder, Maggie Schauer, Frank Neuner, Brigitte Rockstroh, Harald Hinkel and Thomas Elbert, 'Screening for Posttraumatic Stress Disorder among Somali ExCombatants: A Validation Study', Conflict and Health 1 (2007) doi: 10.1186/1752-1505-1-10.

70. UNODCCP, East African Drug Information System - Eadis First Annual Meeting (Vienna: United Nations Office for Drug Control and Crime Prevention 2002).

71. Sabrina Grosse-Kettler, 'External Actors in Stateless Somalia: A War Economy and its Promoters', BICC Paper 39 (Bonn: BICC 2005).

72. Anna Maedl, Elisabeth Schauer, Michal Odenwald and Thomas Elbert, 'Psychological Rehabilitation of Ex-Combatants in Non-Western, Post-Conflict Settings' in Erin Martz (ed.) Trauma Rehabilitation after War and Conflict: Community and Individual Perspectives (New York: Springer 2010) pp.177-214.

73. Odenwald et al. (note 66).

74. It was first described by Reno. William Reno, 'War, Markets, and the Reconfiguration of West Africa's Weak States', Comparative Politics 29 (1997) pp.493-510.

75. Seth Kaplan, 'The Remarkable Story of Somaliland', Journal of Democracy 19 (2008) pp.143-57.

76. UN (note 8); UNICEF (note 43); UNSC (note 43); UNICEF (note 50).

77. Odenwald et al. (note 66).

78. Ibid. 